\title{
11. CLUSTERS OF SPONGE SPICULES FROM QUATERNARY SEDIMENTS AT SITES 685 AND 688 OFF PERU ${ }^{1}$
}

\author{
Erlend Martini² and Sigurd Locker ${ }^{3}$
}

\begin{abstract}
Clusters of sponge spicules found in Quaternary deep-water sediments at Sites 685 and 688 off Peru represent single individuals of small sponges or fragments of larger sponges. The spicule assemblages constituting these clusters probably represent a few demosponge species of the subclass Tetractinomorpha and order Astrophorida, because triaenes and microscleric euasters, as well as abundant monaxons, are present. As proved by incorporated Neogene diatoms, these spicule clusters are allochthonous. The sponge individuals probably inhabited deeper neritic environments during late Neogene time.
\end{abstract}

\section{INTRODUCTION}

Sponge spicules were noted as minor constituents of the regular siliceous microfossil assemblages in most of the lower Miocene to Holocene sequences drilled during Ocean Drilling Program Leg 112 off Peru (Fig. 1). These spicules are associated with common diatoms, few silicoflagellates, and scattered radiolarians. From 10 sites drilled (679 through 688), the Quaternary sequences of Sites 685 and 688 were selected to study the occurrence of isolated sponge spicules and of frequently observed clusters of sponge spicules.

Site $685\left(9^{\circ} 06.78^{\prime} \mathrm{S}, 80^{\circ} 35.01, \mathrm{~W}\right)$ is situated on the lower slope of the Peru Trench, at a water depth of $5070.8 \mathrm{~m}$. The Quaternary sequence consists of $200 \mathrm{~m}$ of diatomaceous mud and contains fossils of Pleistocene age, most of which were transported from the shelf. Site $688\left(11^{\circ} 32.26^{\prime} \mathrm{S}, 78^{\circ} 56.57^{\prime} \mathrm{W}\right)$ is also located on the lower slope of the Peru Trench, in a water depth of $3819.8 \mathrm{~m}$ and about $30 \mathrm{~km}$ landward of the trench axis. Its upper $339 \mathrm{~m}$ is composed of bioturbated Quaternary diatomaceous muds, from which sponge spicules and clusters were recovered and studied. Evidence of reworking and downslope transport is apparent in several fossil groups, but benthic foraminiferal assemblages are representative of present water depths (Suess, von Huene, et al., 1988).

Isolated sponge spicules have been sporadically described and/or depicted in DSDP/ODP publications (Dumitrică, 1973; Hajós, 1973, 1975; Kennett, Houtz, et al., 1975; Bukry, 1978, 1979, 1980a, 1980b; Martini, 1982; Ivanik, 1983; Locker and Martini, 1986; McCartney, 1987; Palmer, 1988), but this study is the first to describe common occurrences of sponge spicules in clusters.

\section{METHODS}

All core-catcher samples from the Quaternary sequences of Holes 685A (Cores 112-685A-1H through $-22 \mathrm{X}$ ) and $688 \mathrm{~A}$ (Cores 112-688A-lH through $-37 \mathrm{X}$ ) were checked for sponge spicules in routine smear slides. From clusters of sponge spicules observed after core splitting, several specimens were

\footnotetext{
${ }^{1}$ Suess, E., von Huene, R., et al., 1990. Proc. ODP, Sci. Results, 112 : College Station, TX (Ocean Drilling Program).

2 Geologisch-Paläontologisches Institut der Universitāt, Senckenberg-Anlage 32-34, D-6000 Frankfurt am Main, Federal Republic of Germany.

${ }^{3}$ Geologisch-Paläontologisches Institut der Universität, Olshausenstrasse 40-60, D-2300 Kiel, Federal Republic of Germany.
}

selected, spread over slides, and mounted in Canada balsam for inspection. Abundances of spicules were estimated from three traverses of $35 \mathrm{~mm}$ long. However, in some slides at least 10 traverses were inspected to obtain data about the diatoms Goniothecium odontella and Diploneis $\mathrm{cf}$. bomboides that were included in the clusters. In Table 1, three classes are used to indicate the number of spicule types found: rare to few $(<5 \%)$, common ( $5 \%$ to $25 \%)$, and abundant to dominant ( $>25 \%$ of the total spicule assemblage).

\section{TERMINOLOGY}

In Table 1, sponge spicules have been differentiated into megascleres, comprising monaxons and tetraxons, and microscleres. Megascleres make up the principal skeleton in Holocene sponges and are usually longer than $100 \mu \mathrm{m}$. Microscleres provide an additional skeleton and are usually smaller than $100 \mu \mathrm{m}$. Both categories of scleres may be subdivided into some morphotypes as a result of their function of supporting different parts of the soft body and the dermal layer (see Hartman, 1981).

Most of the sponge spicules found in the spicule clusters at Sites 685 and 688 represent megascleres; their morphologies and dimensions are shown at the top of Table 1 . Within the basic types of monaxons and tetraxons, megascleres were classified into specific types of spicules (oxes, strongyles, tyles, styles, caltrops, tripods, and triaenes), which are further distinguished by prefixes, according to Schulze and Lendenfeld (1889) and Rauff (1893/1894).

Small microscleres may have been lost from most of the spicule clusters during deposition; thus, mainly some larger, but nevertheless diagnostic, spicule types (oxes, sigmas, diancisters, and asters) were noted. If possible, these types were also characterized by prefixes.

As noted above, the terminology of Schulze and Lendenfeld (1889) and Rauff (1893/1894) was adopted here to label these sponge spicules. In general, for their terminology these authors relied on Greek words, from which the Greek endings were omitted. Thus, all special terms received the same orthographic level, which contrasts with later usage, where words having deviated endings (such as chela, oxea, tylote, a.o.) and those without endings (such as strongyle, style, a.o.) were mixed to describe taxonomy (see Laubenfels, 1955; Bukry, 1978; Wiedenmayer, 1977). To accommodate common English, respective endings have been added to certain terms. 


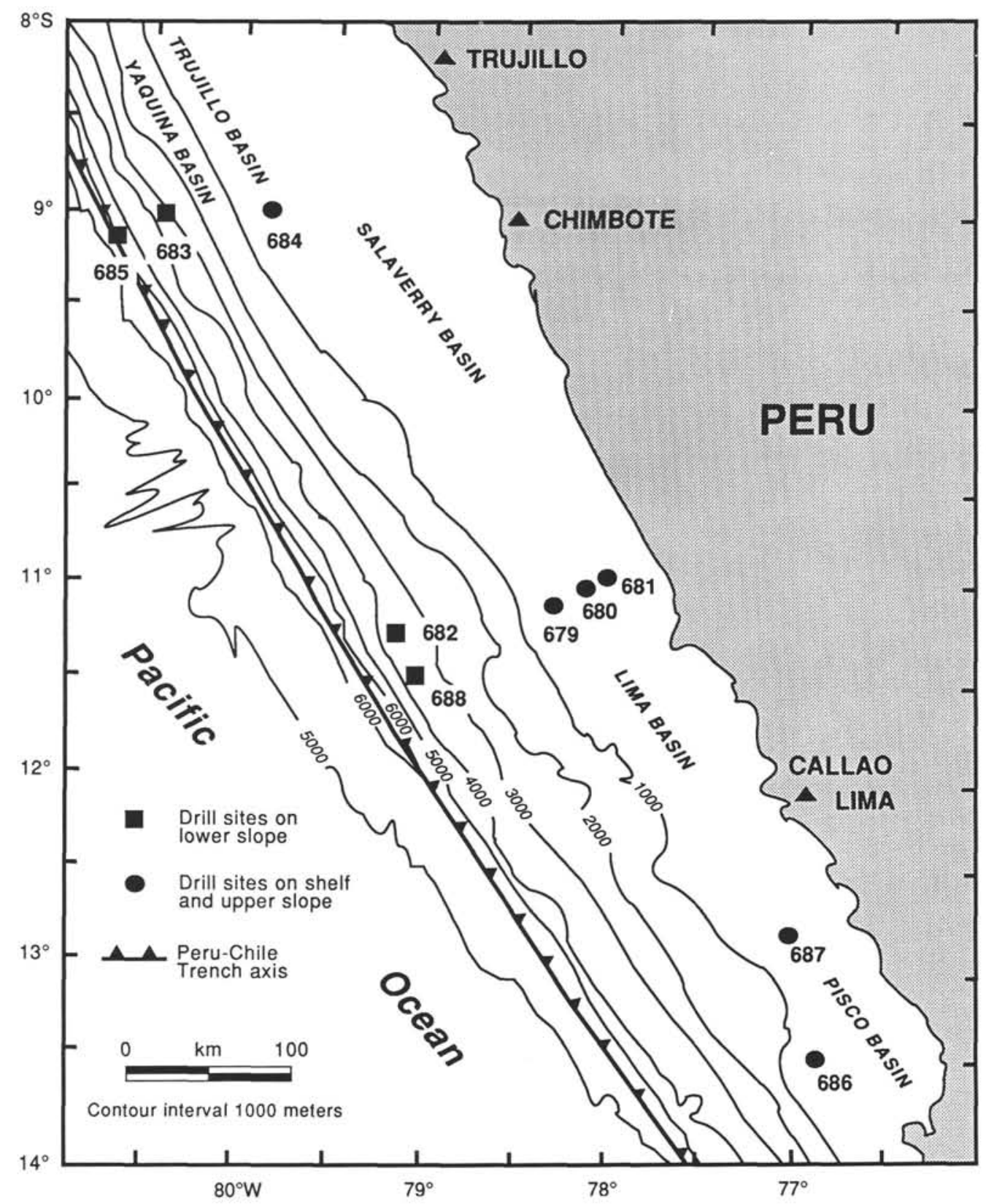

Figure 1. Location of sites drilled during Leg 112 in the eastern South Pacific off Peru. Contours in meters.

\section{OCCURRENCES OF SPONGE SPICULES}

\section{Sponge Spicules in the Matrix of Sediments}

Isolated sponge spicules provide only rare constituents of the Quaternary sediments at Sites 685 and 688 and represent mainly oxoid, strongyloid, and tyloid fragments of megascleres. Microscleres are evident by some sigmas and asters. Since all these spicules are found throughout the section, they are believed to be autochtonous.

\section{Spicules in Clusters}

Besides the rare sponge spicules noted above, whitish clusters containing abundant sponge spicules also were found in the upper part of the Quaternary sequence at Site 685 and in most of the Quaternary sequence at Site 688. They are preserved as compressed globular to ovoid bodies, ranging in diameter from 2 to $5 \mathrm{~mm}$ and having an inner cavity filled with sediment (Fig. 2). These clusters may represent single individuals of small sponges or fragments of partitioned larger ones. Most specimens are scattered throughout the diatomaceous muds (Suess, von Huene, et al., 1988, p. 605, Fig. 8), but some also were found aligned along distinct layers, which, in the case of Sample $112-688 \mathrm{~A}-2 \mathrm{H}-1,85 \mathrm{~cm}$, contained abundant diatom girdles that indicate winnowing and transport.

The clusters of sponge spicules are composed of various monaxonic and tetraxonic megascleres, with a few types of microscleres (Table 1). A total of 18 types of megascleres and five types of microscleres were found. Megascleres are represented mainly by monaxons, especially oxes, styles, tyles, and strongyles. Tetraxons include caltrops, triaenes, and tripods; and microscleres contain oxes, sigmas, diancisters, and asters. 
Table 1. Distribution of sponge spicule types, Goniothecium odontella and Diploneis cf. bomboides in selected spicule clusters from Quaternary sediments in Holes 685A and 688A.

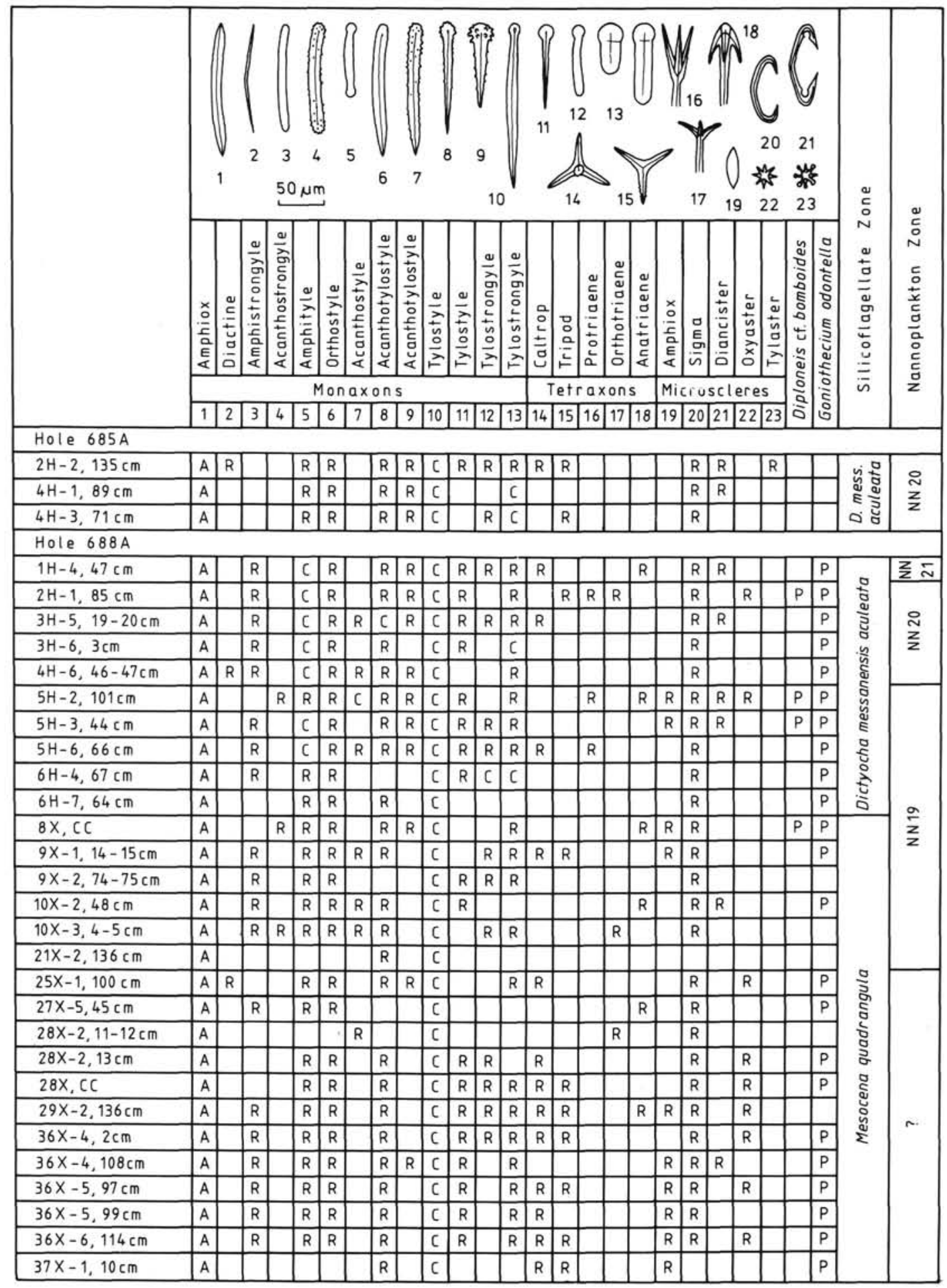

Note: $\mathrm{R}=$ rare to few, $\mathrm{C}=$ common, $\mathrm{A}=$ abundant to dominant, $\mathrm{P}=$ present.

Dominant constituents of all clusters are smooth amphioxes (type 1 in Table 1; Pl. 1, Fig. 12) having a varying diameter and length. Besides these spicules, long tylostyles (type 10; Pl. 1, Figs. 7 and 16) are common throughout the samples, followed by distinct amphityles (type 5; PI. 1, Fig. 5) that are common only in the upper part of the stratigraphic column. Common occurences of characteristic massive tylo- strongyles (type 13; Pl. 1, Fig. 1) are restricted to certain horizons of the upper Quaternary. All other megascleres and microscleres are only minor constituents of the spicule assemblages, although some types may be conspicuous. This is true, in particular, for certain spiny-headed tylostyles (type 9; no figure in $\mathrm{Pl} .1$ ), pin-shaped tylostyles (type 11; no figure in $\mathrm{Pl}$. 1), and smooth tylostrongyles (type 12; no figure in $\mathrm{Pl}$. 1). The 

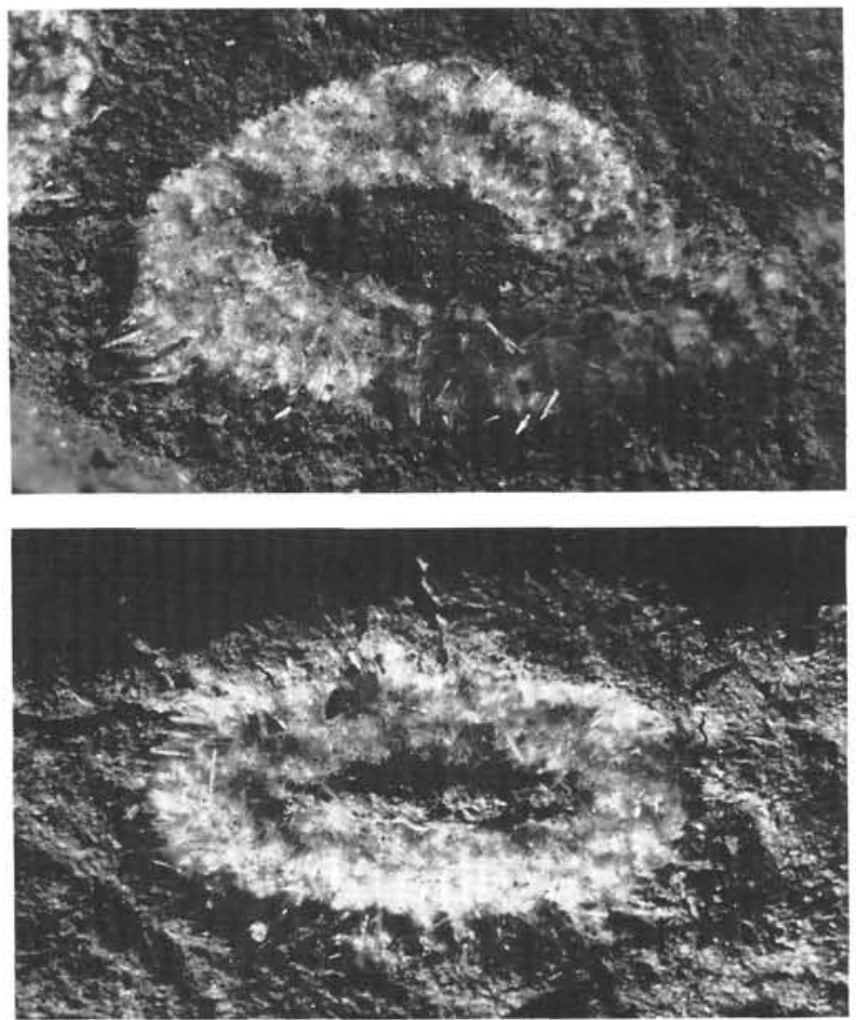

Figure 2. Clusters of sponge spicules from Samples 112-688A-28X-2, 11-12 cm (above) and 112-688A-27X-6, 4-5 cm (below); Quaternary. $(\mathrm{LM}$; specimens magnified $\times 22)$.

morphologies of remaining tetraxonic megascleres and of microscleres have no peculiarities and occur within the known ranges of variability.

\section{DISCUSSION}

1. Taxonomy: The unusual type of preservation described above indicates that the clusters of siliceous spicules represent single individuals of small sponges or parts of larger ones. The rather uniform spicule assemblages noted from the clusters demonstrate that a group of closely related demosponge species may be present. Because triaenes and microscleric euasters, as well as abundant monaxons, were found, these species may be placed in the subclass Tetractinomorpha and order Astrophorida (compare characters of categories in Lévi, 1973; Kilian, 1980; Hartman, 1981).

2. Stratigraphy: Differences between the composition of spicule clusters and sponge spicule assemblages in the studied sediments indicate that these clusters may be allochthonous. This is confirmed, in particular, by occurrences of the diatoms Goniothecium odontella and Diploneis cf. bomboides (Table $1)$, which are exceptional in some respect. At Site 688 most of the clusters studied contain resting cysts of $G$. odontella $(\mathrm{Pl}$. 1, Fig. 2) that were not found in the surrounding sediments. $G$. odontella was reported from Oligocene and Miocene strata in the Norwegian Sea during DSDP Leg 38 and is present also in Pliocene sequences elsewhere (Schrader and Fenner, 1976), but seems to be extinct in the Quaternary. In some cases, the shallow-water benthic diatom D. cf. bomboides (Pl. 1, Fig. 3) was noted in the clusters, which is not in accordance with benthic foraminiferal data, which indicate a deep-water environment at Site 688 for Quaternary time (Resig, this volume). Other fossil groups, e.g., silicoflagellates, indicate displaced specimens from older, especially Miocene, strata in the Qua- ternary sequence of Hole 688A (Martini, this volume). The presence of type 13 tylostrongyles in most of the clusters may indicate reworking of late Neogene strata, as these types were originally described from the upper Miocene at DSDP Site 604 in the Northwest Atlantic (McCartney, 1987).

3. Ecology: Holocene tetractinomorph demosponges inhabit littoral to hadal environments, but are most common in neritic areas down to about $100 \mathrm{~m}$ deep (Vacelet and Vacelet, 1973). The distinct globular to ovoid shape of spicule clusters, embracing a wide internal cavity, and the shallow-water diatom Diploneis cf. bomboides, found within the clusters, may indicate that these sponges grew on the deeper shelf during late Neogene time.

\section{ACKNOWLEDGMENTS}

We thank the Deutsche Forschungsgemeinschaft (Bonn) for supporting this study. We also thank H. J. Schrader (Bergen) and J. Fenner (Kiel) for identifying some diatoms, and A. A. Palmer for reviewing the manuscript.

\section{REFERENCES}

Bukry, D., 1978. Cenozoic coccolith, silicoflagellate, and diatom stratigraphy, Deep Sea Drilling Project Leg 44. In Benson, W. E., Sheridan, R. E., et al., Init. Repts. DSDP, 44: Washington (U.S. Govt. Printing Office), 807-863.

1979. Coccolith and silicoflagellate stratigraphy, northern Mid-Atlantic Ridge and Reykjanes Ridge, Deep Sea Drilling Project Leg 49. In Luyendyk, B. P., Cann, J. R., et al., Init. Repts. DSDP, 49: Washington (U.S. Govt. Printing Office), 551-581.

1980a. Eocene diatoms and siliceous sponge spicules from the northwestern Atlantic Ocean, DSDP Sites 417 and 418. In Donelly, T., Francheteau, J., et al., Init. Repts. DSDP, 51-53 (Pt. 2): Washington (U.S. Govt. Printing Office), 851-855.

$1980 \mathrm{~b}$. Silicoflagellate biostratigraphy and paleoecology in the eastern equatorial Pacific, Deep Sea Drilling Project Leg 54. In Rosendahl, B. R., Hekinian, R., et al., Init. Repts. DSDP, 54: Washington (U.S. Govt. Printing Office), 545-573.

Dumitrică, P., 1973. Cretaceous and Quaternary radiolaria in deep sea sediments from the Northwest Atlantic Ocean and Mediterranean Sea. In Ryan, W.B.F., Hsü, K. J., et al., Init. Repts. DSDP, 13 (Pt. 2): Washington (U.S. Govt. Printing Office), 829-901.

Hajós, M., 1973. The Mediterranean diatoms. In Ryan, W.B.F., Hsü K. J., et al., Init. Repts. DSDP, 13 (Pt. 2): Washington (U.S. Govt. Printing Office), 944-969.

1975. Late Cretaceous archaeomonadaceae, diatomaceae and silicoflagellatae from the South Pacific Ocean, Deep Sea Drilling Project, Leg 29, Site 275. In Kennett, J. P., Houtz, R. E., et al., Init. Repts. DSDP, 29: Washington (U.S. Govt. Printing Office), 913-1009.

Hartman, W. D., 1981. Form and distribution of silica in Sponges. In Simpson, T. L., and Volcani, B. E. (Eds.), Silicon and Siliceous Structures in Biological Systems: New York-Heidelberg-Berlin (Springer-Verlag), 453-493.

Ivanik, M. M., 1983. Paleogene and Neogene sponge spicules from Sites 511, 512, and 513 in the South Atlantic. In Ludwig, W. J., Krasheninnikov, V. A., et al., Init. Repts. DSDP, 71 (Pt. 2): Washington (U.S. Govt. Printing Office), 933-950.

Kennett, J. P., Houtz, R. E., et al., 1975. Site 282. In Kennett, J. P., Houtz, R. E., et al., Init. Repts. DSDP, 29: Washington (U.S. Govt. Printing Office), 317-363.

Kilian, E. F., 1980. Stamm Porifera, Schwämme. In Gruner, H. E. (Ed.), Lehrbuch der Speziellen Zoologie, 1 (1): Jena (Gustav Fischer), 251-288, 296-297.

Laubenfels, M. W. de, 1955. Porifera. In Moore, R. C. (Ed.), Treatise on Invertebrate Paleontology, E: Lawrence (Univ. of Kansas Press), 21-112.

Lévi, C., 1973. Systématique de la classe de Démospongiaria (Démosponges), In Grassé, P. P. (Ed.), Traité de Zoologie, 3(1): Paris (Masson), 577-631.

Locker, S., and Martini, E., 1986. Silicoflagellates and some sponge spicules from the Southwest Pacific, Deep Sea Drilling Project Leg 
90. In Kennett, J. P., von der Borch, C. C., et al., Init. Repts. DSDP, 90: Washington (U.S. Govt. Printing Office), 887-924.

Martini, E., 1982. Pliocene and Quaternary diatoms, silicoflagellates, sponge spicules, and endoskeletal dinoflagellates from the Philippine Sea, Deep Sea Drilling Project Legs 59 and 60. In Hussong, D. M., Uyeda, S., et al., Init. Repts. DSDP, 60: Washington (U.S. Govt. Printing Office), 565-574.

McCartney, K., 1987. Siliceous sponge spicules from Deep Sea Drilling Project Leg 93. In Van Hinte, J. E., Wise, S. W., Jr., et al., Init. Repts. DSDP, 93: Washington (U.S. Govt. Printing Office), 815-824.

Palmer, A. A., 1988. Paleoenvionmental significance of silicoues spponge spicules from Sites 627 and 628, Little Bahama Bank, Ocean Drilling Program Leg 101. In Austin, J. A., Jr., Schlager, W., et al., Proc. ODP, Sci. Results, 101: College Station, TX (Ocean Drilling Program), 159-168.

Rauff, H., 1893/1894. Palaeospongiologie. Allgemeiner Theil. Palaeontographica, 40:1-232.
Schrader, H. J., and Fenner, J., 1976. Norwegian Sea Cenozoic diatom biostratigraphy and taxonomy. In Talwani, M., Udintsev, G., et al., Init. Repts. DSDP, 38: Washington (U.S. Govt. Printing Office), 921-1099.

Schulze, F. E., and Lendenfeld, R. von, 1889. Uber die Bezeichnung der Spongiennadeln. Abh. Königl. Preuss. Akad. Wiss. Berlin, phys.-math. Kl., 1889:1-35.

Suess, E., von Huene, R., et al., 1988. Proc. ODP, Init. Repts., 112: College Station, TX (Ocean Drilling Program).

Vacelet, M. S., and Vacelet, J., 1973. Écologie des Démosponges. In Grassé, P. P. (Ed.), Traité de Zoologie, 3(1):462-576.

Wiedenmayer, F., 1977. Shallow-water sponges of the western Bahamas. Experientia, Suppl. 28:1-287.

Date of initial receipt: 2 February 1989

Date of acceptance: 1 June 1989

Ms 112B-179 

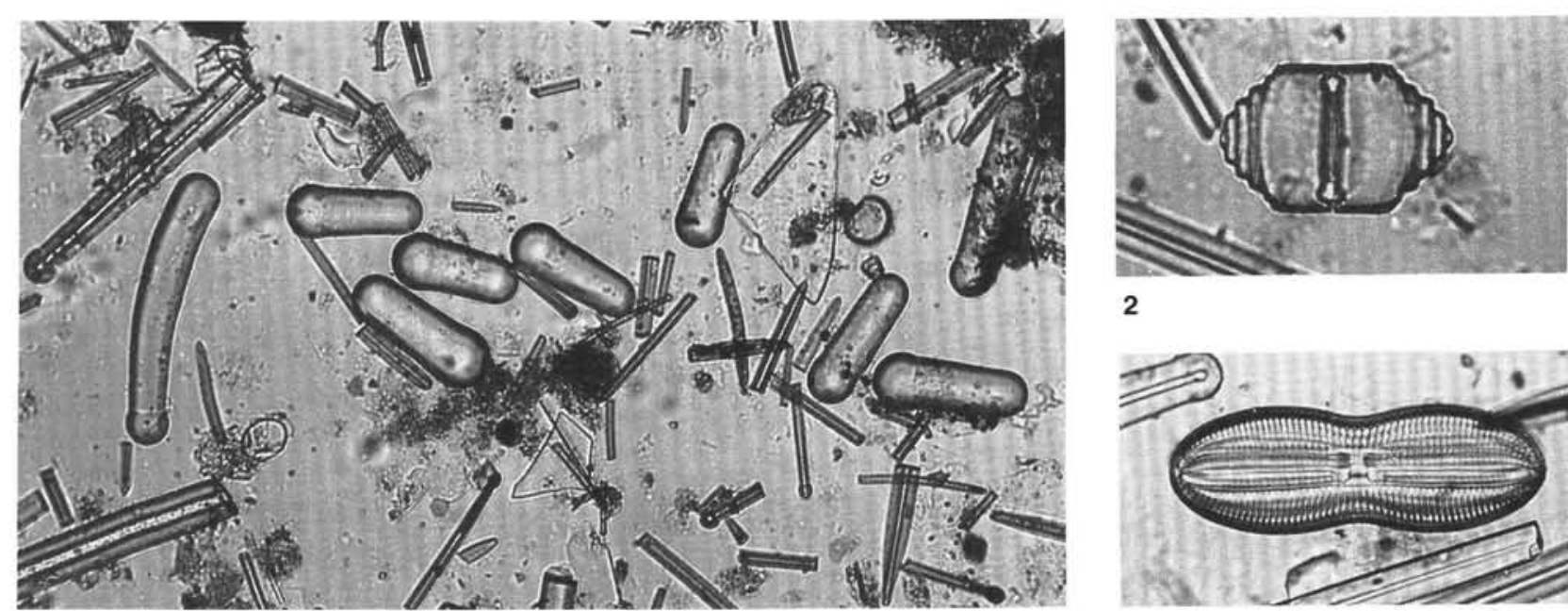

2

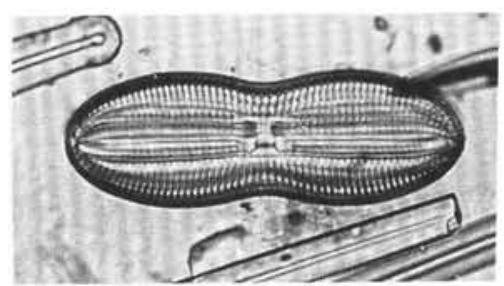

3

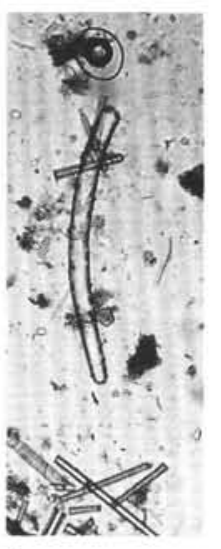

4

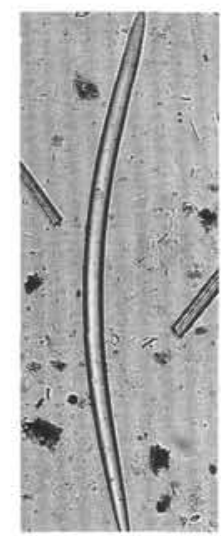

12

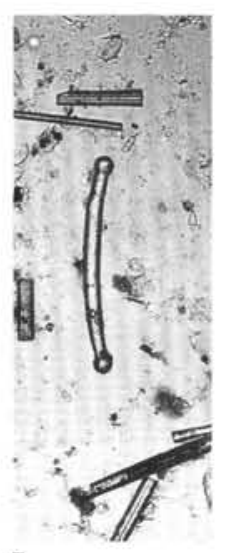

5

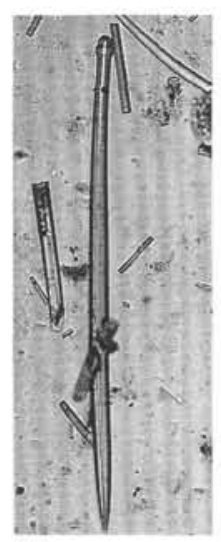

13

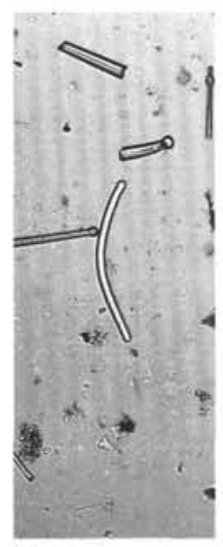

6

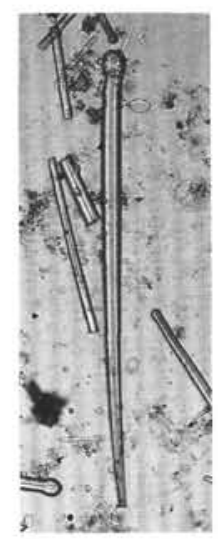

14

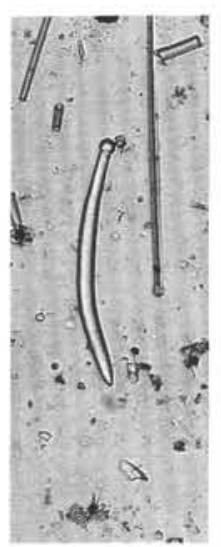

7

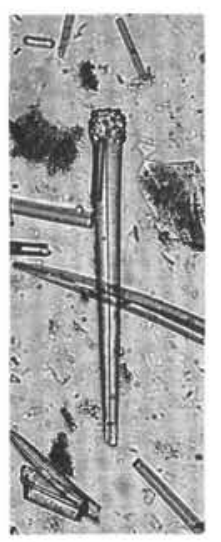

15

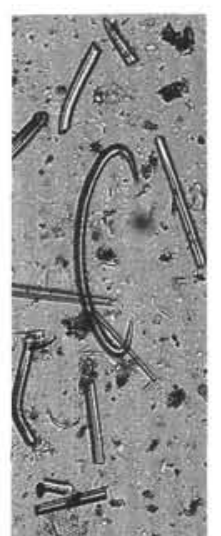

8

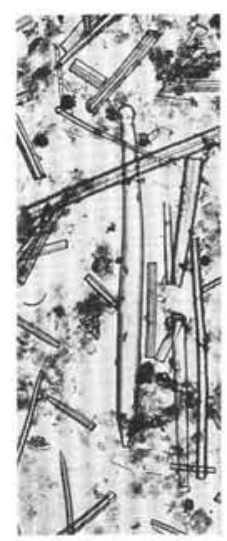

16

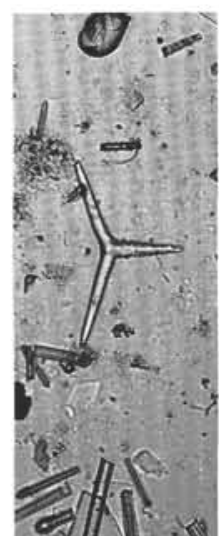

9

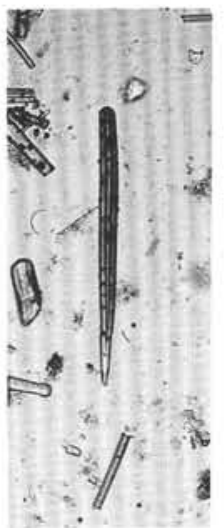

17

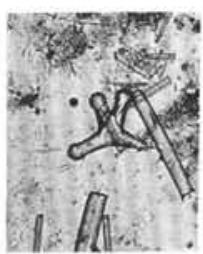

10

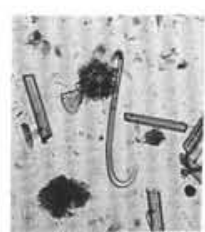

11

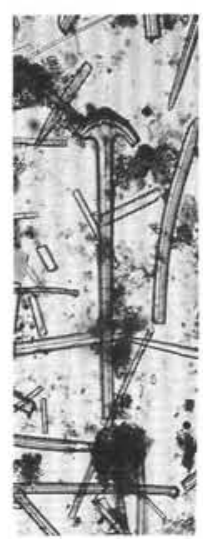

18

Plate 1. Sponge spicules and some diatoms from spicule clusters found in Quaternary sediments. (LM; specimens magnified X130 in Fig. 1, X400 in Figs. 2 and 3, and X100 in Figs. 4 through 18). 1. Sponge cluster with common massive tylostrongyles, spicule type 13, Sample 112-685A-4H-3, $71 \mathrm{~cm}$. 2. Goniothecium odontella, Sample 112-688A-3H-6, $3 \mathrm{~cm}$. 3. Diploneis cf. bomboides, Sample 112-688A-5H-2, $101 \mathrm{~cm}$. 4. Acanthostrongyle, type 4, Sample 112-688A-10X-3, 4-5 cm. 5. Amphityle, type 5, Sample 112-688A-29X-2, $136 \mathrm{~cm} .6$. Amphistrongyle, type 3, Sample 112-688A-3H-5, 19-20 cm. 7. Tylostyle, type 10, Sample 112-688A-10X-3, 4-5 cm. 8. Sigma, type 20, Sample 112-688A-10X-3, 4-5 cm. 9. Tripod, type 15, Sample $112-685 \mathrm{~A}-4 \mathrm{H}-3,71 \mathrm{~cm}$. 10. Fragment of tylaster, type 23 , Sample 112-685A-2H-2, $135 \mathrm{~cm}$. 11. Sigma, included in type 20, 112-688A-10X-3, 4-5 cm. 12. Amphiox, type 1, Sample 112-688A-10X-3, 4-5 $\mathrm{cm}$. 13. Tylostyle, included in type 10, Sample 112-685A-4H-3, $71 \mathrm{~cm}$. 14. Acanthotylostyle, type 8, Sample 112-688A-29X-2, 136 cm. 15. Acanthotylostyle, cf. type 8 , Sample $112-685 \mathrm{~A}-4 \mathrm{H}-3,71 \mathrm{~cm}$. 16. Tylostyle, type 10, Sample 112-688A-29X-2, 136 cm. 17. Orthostyle, type 6, Sample 112-685A-4H-3, $71 \mathrm{~cm}$. 18. Anatriaene, type 18, Sample 112-688A-29X-2, $136 \mathrm{~cm}$. 